\title{
Digestibility and microbial efficiency in steers fed diets based on corn silage hybrids and concentrate levels
}

\author{
[Digestibilidade e eficiência microbiana em novilhos alimentados com dietas à base de silagem \\ de híbridos de milho e níveis de concentrado] \\ F.H.M. Chizzotti ${ }^{1}$, O.G. Pereira ${ }^{1}$, S.C. Valadares Filho ${ }^{1}$, M.I. Leão ${ }^{1}$, K.G. Ribeiro ${ }^{2}$ \\ ${ }^{1}$ Universidade Federal de Viçosa - Viçosa, MG \\ ${ }^{2}$ Universidade Federal dos Vales do Jequitinhonha e Mucuri - Diamantina, MG
}

\begin{abstract}
A trial involving a $2 \times 2$ factorial design was conducted to evaluate the effect of corn silage hybrids and concentrate levels (25 and 50\%) on intake and digestibility of nutrients, ruminal characteristics and microbial efficiency in steers. Four ruminal and abomasal cannulated steers $(512 \pm 25 \mathrm{~kg}$ of birth weight), were used in a $4 \times 4$ Latin square design. Treatments consisted of $75 \%$ silage A $+25 \%$ concentrate; $50 \%$ silage A $+50 \%$ concentrate; $75 \%$ silage $\mathrm{B}+25 \%$ concentrate; and $50 \%$ silage $\mathrm{B}+50 \%$ concentrate on dry matter (DM) basis. There were no differences in the intakes of $\mathrm{DM}$, organic matter $(\mathrm{OM})$, crude protein, and ether extract. The intake of non fiber carbohydrates and total digestible nutrients were positively affected by concentrate levels. The digestibility of DM and OM were also positively affected by concentrate levels. There were no effects of treatments on ruminal $\mathrm{pH}$ values, ruminal ammonia- $\mathrm{N}$, and microbial efficiency.
\end{abstract}

Keywords: microbial protein synthesis, roughage, total digestible nutrient

\section{RESUMO}

Avaliou-se, em um esquema fatorial 2x2, o efeito de silagem de milho de diferentes híbridos e da porcentagem de concentrado (25 ou 50\%) sobre o consumo e a digestibilidade de nutrientes, os parâmetros ruminais e a síntese de proteína microbiana em bovinos. Utilizaram-se quatro novilhos cruzados $(\mathrm{HxZ})-(512 \pm 25 \mathrm{~kg})-$, fistulados no rúmen e no abomaso, os quais foram distribuídos em um quadrado latino $4 x 4$. Os tratamentos consistiram em $75 \%$ de silagem $A+25 \%$ de concentrado; $50 \%$ de silagem A $+50 \%$ de concentrado; $75 \%$ de silagem $B+25 \%$ de concentrado; e $50 \%$ de silagem $B+50 \%$ de concentrado em $\%$ da matéria seca (MS). Não houve diferença entre os consumos de MS, matéria orgânica (MO), proteína bruta e extrato etéreo, e houve efeito positivo de concentrado sobre os carboidratos não fibrosos e nutrientes digestiveis totais. A digestibilidade da MS e da MO foi positivamente influenciada pela porcentagem de concentrado. Não houve efeito de tratamento sobre o pH e a concentração de amônia ruminais, bem como sobre a eficiência de síntese microbiana.

Palavras-chave: nutrientes digestíveis totais, síntese de proteína microbiana, volumoso

\section{INTRODUCTION}

The feeding is the most expensive component of feedlot systems, mainly the concentrate ration cost. Thus, interactions and impacts of the use of different forage and concentrate ratios are extremely important to analyze the optimal relationship between cost and animal performance. In addition, the quality of silage used is also fundamental to get good economic results, because when using good quality silage, the utilization of concentrate can be decreased and consequently the cost of the diet will be lower.

Whole-plant corn silage is a popular forage source for ruminants due to its high yielding properties, energy content, relatively high palatability, and easy incorporation into total mixed ration. Furthermore, the corn plants have high water soluble carbohydrate content, adequate lactic acid production and, consequently, good results in quality silage.

Recebido em 19 de outubro de 2011

Aceito em 12 de julho de 2012

E-mail: fernandachizzotti@yahoo.com.br 
However, hybrid, maturity, and moisture content are some of the factors that can alter the nutritive value of corn silage (Johnson et al., 2002). Several studies have shown differences between hybrids in nutrient composition of whole plant corn and yield of dry matter (DM; Hunt et al., 1993; Xu et al., 1995; Melo et al., 1999; Oliveira et al., 2003; Qiu et al., 2003). Commercial corn hybrids indicated for silage have been selected on the basis of agronomic traits such as grain yield and disease resistance (Clark et al., 2002) and differences in the nutritive value of whole plant corn silages related to corn genetics have been ignored. Therefore, the choice of hybrid for silage should include agronomic traits and evaluation of nutritive value, as well as the intake and performance of animals fed those silages.

The commercial corn hybrids AGN35-A42 (Agromen) and A3663 (Bayer) are indicated for both corn grain and whole-plant corn silage although feeding trials to evaluate ruminal characteristics and microbial efficiency involving these corn silage hybrids at the same environment condition are limited. The objective of this study was to determine the effects of two corn silage hybrids and two concentrate levels on intake, digestibility, ruminal characteristics, and microbial efficiency in crossbred steers.

\section{MATERIAL AND METHODS}

Two corn hybrids, (Agromen, AGN35-A42, and Bayer, A3663) were used in this trial. Agromen (AGN35-A42) is a double cross hybrid and has an ultra-short-season life cycle while Bayer (A 3663 ) is three-way cross hybrid with a shortseason life cycle. Both corn hybrids are indicated for the production of grains and whole plant silage.

Diets were formulated to be isonitrogenous (13\% crude protein, DM basis). Treatments were factorialized in a $2 \times 2$ arrangement and included the main effects of corn silage hybrids (Agromen, AGN35-A42 and Bayer, A3663) and concentrate levels (25 and 50\%). Treatments consisted of $75 \%$ corn silage A $+25 \%$ concentrate (A25), 50\% corn silage $\mathrm{A}+50 \%$ concentrate (A50), $75 \%$ corn silage $\mathrm{B}+25 \%$ concentrate (B25), 50\% corn silage B $+50 \%$ (B50), on DM basis (Table 2).
Four Holstein x Zebu crossbred steers, averaging $512 \mathrm{~kg} \pm 25 \mathrm{~kg}$ of birth weight $(\mathrm{BW})$, and fitted with abomasal and ruminal cannulas, were used in a $4 \times 4$ Latin Square design to evaluate intake and apparent total tract and partial digestibility of nutrients, ruminal $\mathrm{pH}$ and ammonia-N, and microbial efficiency. Each experimental period had $18 \mathrm{~d}$ : $10 \mathrm{~d}$ for diet adaptation, $6 \mathrm{~d}$ to collect fecal and abomasal samples, $1 \mathrm{~d}$ for ruminal $\mathrm{pH}$ measurements and collection of ruminal fluid samples, and $1 \mathrm{~d}$ to collect ruminal contents to isolate bacteria. The experiment was conducted for $72 \mathrm{~d}$ (4 periods of $18 \mathrm{~d}$ ). Steers were surgically fitted with ruminal and abomasal cannulaes in agreement with techniques described by Leão and Coelho da Silva (1980).

Steers were randomly assigned to four dietary treatment sequences and fed individually ad libitum twice daily (07:00 and 15:00h). Diets were fed as total mixed ration, being corn silage and concentrate (previously mixed) weighed and mixed at feeding time. Orts were collected and weighed once daily and the feed offered was adjusted daily to yield orts of about 5 to $10 \%$ of total offered. Animals had free access to water at all times. Feed ingredients and orts were sampled daily and composed by weight for each steer within each period.

Feces and abomasal digesta samples (approx. $200 \mathrm{~g}$ and $500 \mathrm{~mL}$, respectively) were collected between the $\mathrm{d} 11$ and 16 of each period with intervals of $26 \mathrm{~h}$ between the samplings. Indigestible acid detergent fiber (iADF) was used as an internal marker to estimate apparent nutrient digestibility and fecal and abomasal output. After drying at $60^{\circ} \mathrm{C}$ for $72 \mathrm{~h}$, feed, orts, and fecal and abomasal samples were ground to pass a 1-mm screen (Willey mill) and period composites per steer were prepared.

Ruminal contents $(100 \mathrm{~mL})$ were obtained at 0,1 , 2, 4, 6 and $8 \mathrm{~h}$ after the morning feeding on $\mathrm{d} 17$ of each period and subsequently strained through 2 layers of cheesecloth. $\mathrm{pH}$ was measured immediately. The ruminal fluid was preserved through the addition of $1 \mathrm{~mL}$ of $9 \mathrm{M} \mathrm{H}_{2} \mathrm{SO}_{4}$, and stored at $-20^{\circ} \mathrm{C}$ for analyses of $\mathrm{NH}_{3}-\mathrm{N}$ concentration.

On d 18, the rumen contents were obtained $4 \mathrm{~h}$ post-feeding and squeezed through two layers of cheesecloth to yield about $1,500 \mathrm{~mL}$ of strained 
fluid. Particles retained on the cheesecloth were mixed with $500 \mathrm{~mL}$ of $9 \mathrm{~g}$ of $\mathrm{NaCl} / \mathrm{L}$, blended for $1 \mathrm{~min}$, refiltered through cheesecloth, and added to the $1.5 \mathrm{~L}$ ruminal fluid sample. Bacteria were isolated by differential centrifugation $(500 \mathrm{~g}$ and $27,000 \mathrm{~g}$ ) according to procedures by Cecava et al. (1990). The resulting bacterial pellets were dried at $60^{\circ} \mathrm{C}$ for $48 \mathrm{~h}$ and ground in a ball mill. The dried bacterial samples were ground and analyzed for DM, ash, and total N, and total purines were determined as proposed by Ushida et al. (1985).

The composite sample for each material (silage, concentrate, orts, abomasal digesta, and feces) was used to determine the DM (method \#934.01 (Official..., 1990); organic matter determined by ash (method \#924.05 (Official..., 1990); crude protein $(\mathrm{CP})$ obtained by total $\mathrm{N}$ determination using the micro Kjeldahl technique (method \#920.87 (Official..., 1990) and a fixed conversion factor (6.25); eter extract (EE) determined gravimetrically after extraction using petroleum ether in a Soxhlet instrument (method \#920.85 (Official..., 1990); neutral detergent fiber (NDF) Van Soest et al., 1991); ADF (method \#973.18 (Official..., 1990), and sulfuric acid lignin (Van Soest et al., 1991). The iADF (ADF remaining after a $144 \mathrm{~h}$ in situ incubation in a rumen-cannulated cow) was determined according to Cochran et al. (1986).

Non-fiber carbohydrates (NFC) were calculated by difference as shown in Equation 1

$\mathrm{NFC}=100-[\% \mathrm{CP}+\% \mathrm{NDF}+\% \mathrm{EE}+\%$ ash $]$ [1]

Apparent total digestible nutrients (ApTDN) were calculated as shown in Equation 2 (NRC, 2001).
App $\mathrm{TDN}=($ digestible $\mathrm{CP}+$ digestible $\mathrm{NDF}+$ digestible $\mathrm{NFC}+(2.25 \times$ digestible EE $)) /$ DMI. [2]

The determinations of the contents of NH3-N of ruminal and abomasal fluid samples were done according to the original procedures by of Fenner (1965) and adaptations by Vieira (1980). To quantify microbial protein and subsequently determine microbial efficiency, approximately $400 \mathrm{mg}$ of dry abomasal digesta samples were used, which were also analyzed for purines according to Ushida et al. (1985).

Data of intake, digestibility, and microbial efficiency were analyzed with the GLM procedure of SAS assuming a $4 \times 4$ Latin square design with a $2 \times 2$ factorial arrangement of treatments. The ruminal characteristics data collected over time were analyzed as repeated measures (Kuehl, 2000) using the MIXED procedure by SAS (Statistical..., 1990). When treatment interacted $(P<0.05)$ with sampling time, variables were analyzed within time periods. The variance-covariance structure AR(1) was used for estimating covariances. Differences were considered to be significant when $P \leq 0.05$.

\section{RESULTS}

The chemical composition of silages is presented in Table 1. Both corn silage hybrids had similar nutrient values, except for DM and NFC, which were numerically lower in corn silage hybrid A than those observed in corn silage hybrid B. In addition, corn silage $\mathrm{A}$ had a $\mathrm{pH}$ value of 3.6 and $\mathrm{N}-\mathrm{NH}_{3} /$ Total $\mathrm{N}$ of $8.4 \%$ while corn silage $\mathrm{B}$ had a pH of 3.5 and $\mathrm{N}-\mathrm{NH}_{3} /$ Total $\mathrm{N}$ of $6.3 \%$.

Table 1. Chemical composition of corn silages

\begin{tabular}{lcc}
\hline Item & Corn silage A & Corn silage B \\
\hline $\mathrm{DM}, \%$ & 28.01 & 32.45 \\
$\mathrm{OM}, \%$ of DM & 96.12 & 96.02 \\
$\mathrm{CP}, \%$ of DM & 7.00 & 6.02 \\
$\mathrm{NDF}, \%$ of DM & 53.00 & 51.14 \\
$\mathrm{iADF}, \%$ of DM & 12.50 & 11.80 \\
$\mathrm{EE}, \%$ of DM & 2.25 & 2.02 \\
$\mathrm{NFC}, \%$ of DM & 33.87 & 36.86 \\
$\mathrm{Lignin}, \%$ of DM & 3.62 & 3.45 \\
pH & 3.60 & 3.50 \\
$\mathrm{NH}{ }_{3}-\mathrm{N}, \%$ total N & 8.40 & 6.30 \\
\hline $\mathrm{DM}=$ dry matter; OM = organic matter; CP = crude protein; NDF = neutral detergent fiber; iADF = indigestible \\
$\mathrm{ADF}$, EE = ether extract and NFC = non-fiber carbohydrates.
\end{tabular}


The nutrient composition of the diets is shown in Table 2 . As expected, diets with $50 \%$ concentrate provided higher amounts of DM, NFC and TDN than diets with $25 \%$ concentrate. The intake of nutrients is shown in Table 3. There were no treatment effects $(P>0.05)$ on the intakes of DM, $\mathrm{OM}, \mathrm{CP}$, and EE. The intakes of NDF, NFC and TDN were influenced $(P<0.05)$ by concentrate levels.

Table 2. Ration composition and analyzed content in diets

\begin{tabular}{lcccc} 
& \multicolumn{2}{c}{ Corn Silage A } & \multicolumn{2}{c}{ Corn Silage B } \\
\cline { 2 - 5 } Item & 25 & 50 & 25 & 50 \\
\hline Corn silage & 75.0 & 50.0 & 75.0 & 50.0 \\
Ground corn & 14.86 & 41.0 & 14.86 & 41.0 \\
Cottonseed meal & 8.27 & 7.03 & 8.27 & 7.03 \\
Urea & 1.00 & 1.00 & 1.00 & 1.00 \\
Ammonium sulfate & 0.10 & 0.10 & 0.10 & 0.10 \\
Sodium chloride & 0.25 & 0.25 & 0.25 & 0.25 \\
Calcite limestone & 0.50 & 0.60 & 0.50 & 0.60 \\
Mineral premix & 0.02 & 0.02 & 0.02 & 0.02 \\
& & Nutrient content in diets & 61.60 \\
DM, \% & 43.53 & 59.38 & 46.91 & 94.39 \\
OM, \% of DM & 94.28 & 94.44 & 94.20 & 12.64 \\
CP, \% of DM & 13.06 & 13.13 & 12.32 & 31.80 \\
NDF, \% of DM & 43.74 & 32.73 & 42.35 & 7.10 \\
iADF, \% of DM & 10.58 & 7.45 & 10.06 & 2.02 \\
EE, \% of DM & 2.14 & 2.15 & 1.95 & 51.95 \\
NFC, \% of DM & 38.81 & 50.46 & 41.04 & 2.37 \\
Lignin, \% of DM & 3.16 & 2.46 & 3.03 & . \\
\hline
\end{tabular}

${ }^{1}$ Composition (\%): cooper sulfate (22.50), cobalt sulfate (1.40), zinc sulfate (75.40), potassium iodate (0.50), sodium selenite $(0.20)$. $\mathrm{DM}=$ dry matter; $\mathrm{OM}=$ organic matter; $\mathrm{CP}=$ crude protein; $\mathrm{NDF}=$ neutral detergent fiber; $\mathrm{ADF}=$ acid detergent fiber; $\mathrm{iADF}=$ indigestible $\mathrm{ADF} ; \mathrm{EE}=$ ether extract; and $\mathrm{NFC}=$ non-fiber carbohydrates.

Table 3. Nutrient intake according to corn silage hybrids and concentrate levels

\begin{tabular}{|c|c|c|c|c|c|c|c|c|}
\hline \multirow[b]{3}{*}{ Item } & \multicolumn{2}{|c|}{ Corn silage A } & \multicolumn{2}{|c|}{ Corn silage B } & \multirow{3}{*}{ SEM } & \multicolumn{3}{|c|}{$P$-value } \\
\hline & 25 & 50 & 25 & 50 & & Silage & Conc & $\mathrm{S} \times \mathrm{C}$ \\
\hline & \multicolumn{4}{|c|}{ Intake, $\mathrm{kg} / \mathrm{d}$} & & & & \\
\hline $\mathrm{DM}$ & 10.97 & 11.12 & 10.22 & 11.79 & 0.62 & 0.94 & 0.21 & 0.30 \\
\hline $\mathrm{OM}$ & 10.49 & 10.71 & 9.78 & 11.44 & 0.59 & 0.99 & 0.16 & 0.27 \\
\hline $\mathrm{CP}$ & 1.48 & 1.47 & 1.32 & 1.53 & 0.08 & 0.55 & 0.24 & 0.17 \\
\hline $\mathrm{EE}$ & 0.24 & 0.22 & 0.21 & 0.23 & 0.02 & 0.64 & 0.83 & 0.33 \\
\hline $\mathrm{NDF}$ & 4.61 & 3.23 & 4.17 & 3.29 & 0.35 & 0.61 & 0.02 & 0.49 \\
\hline NFC & 4.46 & 6.07 & 4.17 & 6.44 & 0.23 & 0.87 & $<0.001$ & 0.21 \\
\hline \multirow[t]{2}{*}{ TDN } & 7.38 & 8.13 & 6.62 & 8.45 & 0.47 & 0.66 & 0.03 & 0.29 \\
\hline & \multicolumn{4}{|c|}{ Intake, $\%$ of $\mathrm{BW}$} & & & & \\
\hline DM & 1.95 & 1.98 & 1.80 & 2.08 & 0.11 & 0.81 & 0.20 & 0.30 \\
\hline $\mathrm{NDF}$ & 0.82 & 0.58 & 0.74 & 0.58 & 0.06 & 0.54 & 0.02 & 0.51 \\
\hline
\end{tabular}

$\mathrm{DM}=$ dry matter; $\mathrm{OM}=$ organic matter; $\mathrm{CP}=$ crude protein; $\mathrm{EE}=$ ether extract; $\mathrm{ndf}=$ neutral detergent fiber; $\mathrm{NFC}=$ non-fiber carbohydrates; TDN $=$ total digestible nutrients.

$\mathrm{S}=$ silage source effect; $\mathrm{C}=$ concentrate level effect; $\mathrm{S} \times \mathrm{C}=$ silage and concentrate interaction effect.

The digestibility of nutrients is shown in Table 4. Total tract apparent digestibility of DM and OM, as well as a \% of TDN were affected by concentrate levels $(P<0.05)$. The ruminal tract digestibility of nutrients was similar $(P>0.05)$ among all treatments (Table 5). There were no effects of corn silage hybrids on the digestibility of all nutrients in both experiments. There were no treatment effects on ruminal $\mathrm{pH}$ values and ruminal ammonia-N concentrations $(P>0.05)$, and the means are shown in Table 6. 
Digestibility and microbial...

Table 4. Apparent total tract digestibility of nutrients and \% of total digestible nutrients according silage hybrids and concentrate levels

\begin{tabular}{lcccccccc} 
& \multicolumn{2}{c}{ Corn silage A } & \multicolumn{2}{c}{ Corn silage B } & \multicolumn{3}{c}{$P$-value $^{\mathrm{b}}$} \\
\cline { 2 - 9 } Item $^{\mathrm{a}}$ & 25 & 50 & 25 & 50 & SEM & Silage & Concentrate & S x C \\
\hline DM & 66.22 & 71.41 & 64.05 & 71.55 & 2.60 & 0.71 & 0.05 & 0.67 \\
OM & 66.80 & 72.11 & 64.68 & 72.44 & 2.57 & 0.74 & 0.04 & 0.65 \\
CP & 66.77 & 66.88 & 65.87 & 66.81 & 2.51 & 0.85 & 0.84 & 0.87 \\
EE & 78.94 & 76.85 & 78.89 & 79.47 & 2.42 & 0.61 & 0.77 & 0.60 \\
NDF & 53.96 & 49.35 & 53.52 & 54.10 & 3.21 & 0.53 & 0.55 & 0.45 \\
NFC & 79.36 & 85.30 & 75.77 & 81.61 & 2.52 & 0.20 & 0.06 & 0.98 \\
TDN & 67.91 & 73.22 & 64.97 & 71.64 & 2.44 & 0.39 & 0.05 & 0.79 \\
\hline
\end{tabular}

${ }^{a}$ Values are expressed as \%; $\mathrm{DM}=$ dry matter; $\mathrm{OM}=$ organic matter; $\mathrm{CP}=$ crude protein; $\mathrm{EE}=$ ether extract; $\mathrm{NDF}=$ neutral detergent fiber; $\mathrm{NFC}=$ non-fiber carbohydrates; TDN= total digestible nutrients; $\mathrm{S}=$ silage source effect; $\mathrm{C}=$ concentrate level effect; $\mathrm{S} \times \mathrm{C}=$ Silage and concentrate interaction effect.

Table 5. Apparent ruminal tract digestibility of nutrients according to silage hybrids and concentrate levels

\begin{tabular}{lcccccccc} 
& \multicolumn{3}{c}{ Corn silage A } & \multicolumn{2}{c}{ Corn silage B } \\
\cline { 2 - 9 } & 25 & 50 & 25 & 50 & SEM & Silage & Concentrate & S x C \\
\cline { 2 - 9 } Item $^{\text {a }}$ & \multicolumn{3}{c}{ Ruminal tract digestibility } \\
\hline DM & 83.2 & 82.1 & 84.1 & 82.4 & 1.88 & 0.74 & 0.48 & 0.88 \\
OM & 84.3 & 82.7 & 84.9 & 83.2 & 1.73 & 0.73 & 0.39 & 0.98 \\
CP & 55.60 & 58.06 & 53.35 & 60.92 & 3.36 & 0.93 & 0.17 & 0.48 \\
EE & -18.95 & -28.38 & -13.47 & -21.67 & 19.82 & 0.77 & 0.67 & 0.98 \\
NDF & 91.3 & 95.4 & 96.9 & 95.8 & 1.75 & 0.13 & 0.41 & 0.19 \\
NFC & 89.9 & 87.6 & 86.8 & 86.9 & 2.53 & 0.50 & 0.67 & 0.67 \\
\hline
\end{tabular}

${ }^{\mathrm{a}}$ Calculated as \% of digested. $\mathrm{DM}=$ dry matter; $\mathrm{OM}=$ organic matter; $\mathrm{CP}=$ crude protein; $\mathrm{EE}=$ ether extract; $\mathrm{NDF}=$ neutral detergent fiber; $\mathrm{NFC}=$ non-fiber carbohydrates; $\mathrm{S}=$ silage source effect; $\mathrm{C}=$ concentrate level effect; $\mathrm{S} \times \mathrm{C}=$ silage and concentrate interaction effect.

Table 6. Means values of ruminal $\mathrm{pH}$ and ammonia-N concentration after feeding time (hours)

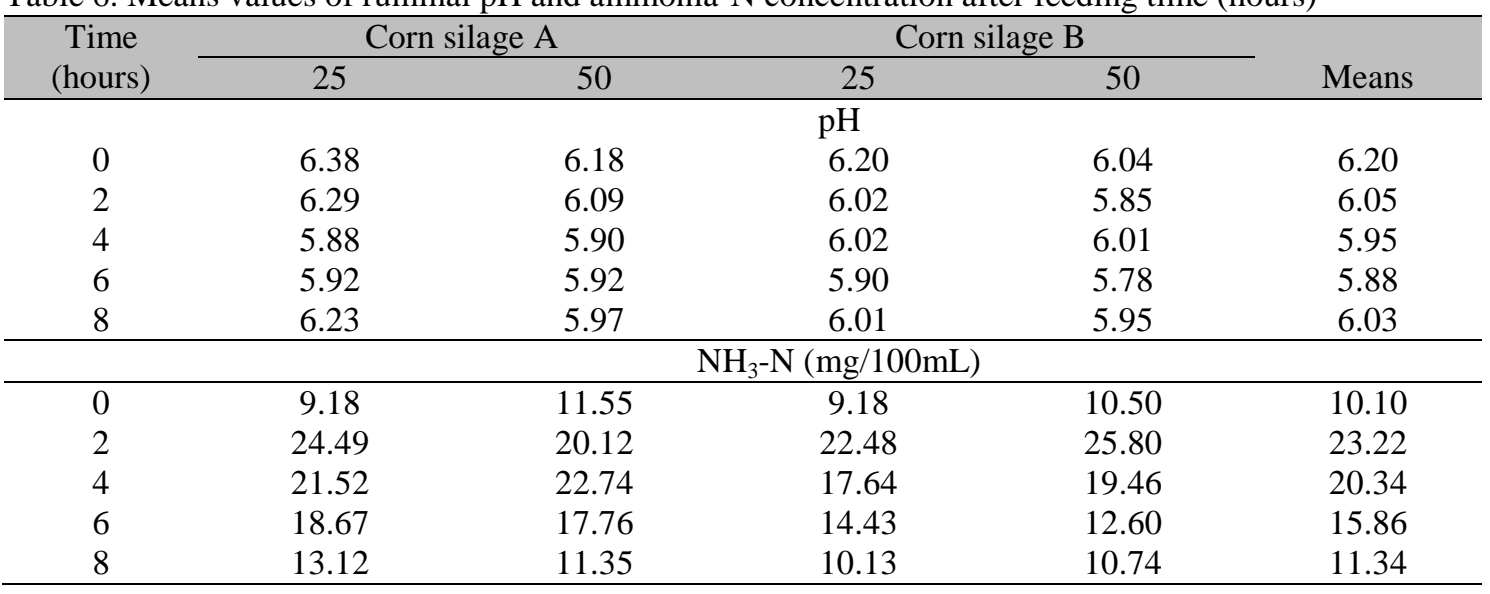

Table 7 shows the data of microbial $\mathrm{N}$ efficiency.

There was a concentrate effect on rumen-degraded organic matter (RDOM) $(P=0.02)$ and rumen-degraded carbohydrate (RDCHO) $(P=0.04)$. However, the efficiency of microbial synthesis, g of microbial N/kg RDOM, $\mathrm{g}$ of microbial $\mathrm{N} / \mathrm{kg}$ RDCHO and $\mathrm{g}$ of microbial crude protein $/ \mathrm{kg}$ TDN were not affected $(P>0.05)$ by treatments. 
Table 7. Microbial N efficiency according to corn silage hybrids and concentrate levels

\begin{tabular}{|c|c|c|c|c|c|c|c|c|}
\hline \multirow[b]{2}{*}{ Item } & \multicolumn{2}{|c|}{ Corn silage A } & \multicolumn{2}{|c|}{ Corn silage B } & \multirow[b]{2}{*}{ SEM } & \multicolumn{3}{|c|}{$P$-value } \\
\hline & 25 & 50 & 25 & 50 & & Silage & Conc & $\mathrm{S} \times \mathrm{C}$ \\
\hline \multicolumn{9}{|c|}{ Rumen degradability, kg/d } \\
\hline $\mathrm{OM}$ & 5.85 & 6.39 & 5.36 & 6.90 & 0.33 & 0.98 & 0.02 & 0.18 \\
\hline $\mathrm{CHO}^{\mathrm{a}}$ & 5.39 & 5.93 & 4.96 & 6.26 & 0.36 & 0.90 & 0.04 & 0.33 \\
\hline \multicolumn{9}{|c|}{ Microbial N efficiency } \\
\hline g mic N/kg RDOM ${ }^{b}$ & 22.29 & 20.09 & 23.71 & 18.80 & 1.86 & 0.97 & 0.11 & 0.50 \\
\hline $\begin{array}{l}\text { g mic N/kg of } \\
\text { RDCHO }^{c}\end{array}$ & 24.28 & 21.70 & 25.59 & 20.74 & 2.11 & 0.94 & 0.13 & 0.61 \\
\hline $\mathrm{g} \mathrm{mic} \mathrm{CP} / \mathrm{kg}$ of TDN & 110.3 & 98.2 & 120.2 & 95.1 & 10.04 & 0.75 & 0.11 & 0.54 \\
\hline
\end{tabular}

$\mathrm{OM}=$ organic matter; $\mathrm{CHO}=$ carbohydrates; $\mathrm{CP}=$ crude protein; $\mathrm{EE}=$ ether extract; $\mathrm{TDN}=$ total digestible nutrients. ${ }^{\mathrm{a}} \mathrm{CHO}=100-(\% \mathrm{CP}+\% \mathrm{EE}+\% \mathrm{Ash})$, Sniffen et al. $(1992) ; \mathrm{RDOM}=$ ruminally degraded organic matter; RDOM $(\mathrm{kg} / \mathrm{d})=$ Intake of $\mathrm{OM}-$ abomasal OM flow; ${ }^{\mathrm{C}} \mathrm{RDCHO}=$ ruminally degraded carbohydrates: $\mathrm{RDCHO}(\mathrm{kg} / \mathrm{d})=$ Intake of $\mathrm{CHO}$ - abomasal $\mathrm{CHO}$ flow; $\mathrm{S}=$ silage source effect; $\mathrm{C}=$ concentrate level effect; $\mathrm{S} \times \mathrm{C}=$ silage and concentrate interaction effect.

\section{DISCUSSION}

Overall, both silages had similar nutrient contents, except for a \% of DM, NDF and NFC (Table 1). Freitas et al. (2003) also observed no effect of silages of five corn genotypes on DM intake and digestibility. According to Muck and Pitt (1993), both silages had good quality due to their adequate percentage of $\mathrm{N}-\mathrm{NH}_{3} /$ Total $\mathrm{N}$ and $\mathrm{pH}$ values. The diets with $50 \%$ concentrate in association with either corn silage hybrids provided higher amounts of DM, NFC and TDN and lower NDF than $25 \%$ concentrate diets, certainly due to a higher percentage of corn ground in those diets.

Although some authors have found linear (Dias et al., 2000; Souza et al. 2002; Pereira et al., 2006) or quadratic (Verás et al., 2000; Ítavo et al., 2002; Silva et al., 2005; Costa et al., 2005) increases in DM intake with an increase of concentrate levels in beef cattle diets, no effects of treatments were observed in this study. Moraes et al. (2002) also found no increase in DM intake with the concentrate levels. These variations among studies probably occurred due to other variables related to the kind of animal, age of animal, climatic conditions, days of feeding, etc, which can affect DM intake.

The higher intake of NFC and TDN and lower intake of NDF in steers fed diets with $50 \%$ concentrate likely occurred as a result of higher amounts of ground corn in these diets than those with $25 \%$. Similar results were found by Costa et al. (2005) who evaluated the effects of concentrate levels $(5,35$, and $65 \%, \mathrm{DM})$ on nutrient intake in Nellore steers. The increases observed in DM and OM digestibility in diets with $50 \%$ concentrate likely occurred due to a higher amount of non-fiber carbohydrates in those diets than in $25 \%$ concentrate diets. In general, the apparent digestibility of NFC is higher than the digestibility of structural carbohydrates, so the replacement of corn silage with corn ground in $50 \%$ concentrate diets provided more NFC to those diets than in $25 \%$ concentrate diets. Similar results were observed by Cardoso et al. (2000), Ítavo et al. (2002), Putrino et al. (2007) and Chizzotti et al. (2010).

NDF apparent digestibility was not affected by concentrate levels, which can be explained by lack of differences in ruminal $\mathrm{pH}$ values (Tab.4). Thus, cellulolytic microbes were not affected by ruminal $\mathrm{pH}$ and, consequently, fiber digestion was not influenced. Pereira et al. (2006) and Costa et al. (2005) observed linear decreases in NDF digestibility as concentrate levels in beef cattle diets increased. The ruminal digestibility of all nutrients was similar among all treatments.

Ruminal $\mathrm{pH}$ values were not affected either by silage or by concentrate levels, which means that the ruminal environment was adequate for microbial growth. Overall, the mean ruminal $\mathrm{pH}$ value observed was 6.02 , which is greater than the 5.0 to 5.5 range that was suggested by Hoover (1986) in which ruminal digestibility of fiber is negatively affected.

In the same way, $\mathrm{NH}_{3}-\mathrm{N}$ concentration was also not affected by treatments and averaged $16.2 \mathrm{mg} / 100 \mathrm{~mL}$. During all time sampling the 
ruminal $\mathrm{NH}_{3}-\mathrm{N}$ concentrations were above levels $(5 \mathrm{mg} / 100 \mathrm{~mL})$ recommended by Satter and Slyter (1974) to optimize ruminal digestion. Pereira et al. (2006) also found no effect of different concentrate levels on ruminal $\mathrm{pH}$ and ruminal $\mathrm{NH}_{3}-\mathrm{N}$ concentrations when steers were fed with sorghum silage and different concentrate levels.

Concentrate levels affected the rumen-degraded $\mathrm{OM}(P=0.02)$ and rumen-degraded carbohydrate $(P=0.04) \quad$ which were higher in steers fed $50 \%$ concentrate diets than in those fed $25 \%$. This increase of ruminal degradability certainly occurred due to higher amounts of ground corn in those diets with more concentrate, which provided more readily fermentable carbohydrates.

Bacterial growth is largely dependent on the amount of ammonia and fermentable organic matter available in the rumen (Bryant and Robinson, 1962). Readily fermentable carbohydrates, such as starch or sugars, are more effective than other carbohydrate sources, such as cellulose, in promoting microbial growth (Stern and Hoover, 1979). Although rumendegraded $\mathrm{OM}$ and rumen-degraded $\mathrm{CHO}$ were higher in $50 \%$ concentrate diets than in those with $25 \%$, microbial $\mathrm{N}$ production (Table 8 ) was not affected by treatments. Moreover, microbial efficiency was also not influenced by treatments $(P>0.05)$ when expressed on a rumen-degraded $\mathrm{OM}$, rumen-degraded carbohydrate, or on a TDN basis. The mean microbial efficiency of $105.95 \mathrm{~g}$ microbial $\mathrm{CP} / \mathrm{kg} \mathrm{TDN}$ is lower than the recommended by National... (1996), which is 130g microbial CP/kg TDN.

\section{CONCLUSIONS}

The association of both corn silage hybrids evaluated with 25 or $50 \%$ concentrate does not affect the ruminal $\mathrm{pH}$ and ruminal ammonia-N concentration, and microbial efficiency. Our findings suggest that, as the two corn silage hybrids evaluated had similar behavior on nutrient intake and microbial efficiency, despite concentrate level, the choice for the more adequate corn silage hybrid should include the agronomic traits.

\section{REFERENCES}

BRYANT, M.P.; ROBINSON, I.M. Some nutritional characteristics of predominant culturable ruminal bacteria. J. Bacteriol, v.84, p.605-614, 1962.

CARDOSO, R.C.; VALADARES FILHO, S.C.; COELHO DA SILVA, J.F. et al. Consumo e digestibilidades aparentes totais e parciais de rações contendo diferentes níveis de concentrado, em novilhos F1 Limousin x Nelore. Rev. Bras. Zootec., v.29, p.1832-1841, 2000.

CECAVA, M.J.; MERCHEN, N.R.; GAY, L.C. et al. Composition of ruminal bacteria harvested from steers as influenced by dietary energy level, feeding frequency, and isolation techniques. $J$. Dairy Sci., v.73, p.2480-2488, 1990.

CHIZZOTTI, F.H.M.; PEREIRA, O.G.; VALADARES FILHO, S.C. et al. Intake, digestibility, and performance of steers fed diets based on two corn silage hybrids and two concentrate levels. Arq. Bras. Med. Vet. Zootec., v.62, p.868-874, 2010.

CLARK, P.W.; KELM, S.; ENDERS, M.I. Effect of feeding a corn hybrid selected for leafiness as silage or grain to lactating dairy cattle. J. Dairy Sci., v.85, p.607-612, 2002.

COCHRAN, R.C.; ADAMS, D.C.; WALLACE, J.D. et al. Predicting digestibility of different diets with internal markers: Evaluation of four potential markers. J. Anim. Sci., v.63, p.14761483, 1986.

COSTA, M.A.L.; VALADARES FILHO. S.C.; PAULINO, M.F. et al. Desempenho, Digestibilidade e Características de Carcaça de Novilhos Zebuínos Alimentados com Dietas Contendo Diferentes Níveis de Concentrado. Rev. Bras. Zootec., v.34, p.268-279, 2005.

DIAS, H.L.C.; VALADARES FILHO, S.C.; COELHO DA SILVA, J.F. et al. Consumo e digestões totais e parciais em novilhos F1 Limousin $\mathrm{x}$ Nelore alimentados com dietas com cinco níveis de concentrado. Rev. Bras. Zootec., v.29, p.545-554, 2000.

FENNER, H. Methods for determining total volatile bases in rumen fluid by steam distillation. J. Dairy Sci., v.48, p.249-251, 1965. 
FREITAS, G.A.R.; COELHO, S.G.; GONÇALVES, L.C. Consumo e digestibilidade aparente da matéria seca, proteína e energia bruta, e balanço de nitrogênio das silagens de cinco genótipos de milho. Arq. Bras. Med. Vet. Zootec., v.55, p.443449, 2003.

HOOVER, W.H. Chemical factors involved on ruminal fiber digestion. J. Dairy Sci., v.69, p.2755-2766, 1986.

HUNT, C.W.; KEZAR, W.D.; HINMAN, D. et al. Effects of hybrid and ensiling with and without a microbial inoculant on the nutritional characteristics of whole-plant corn. J. Anim. Sci., v.71, p.38-43, 1993.

ÍTAVO, L.C.V.; VALADARES FILHO, S.C.; SILVA, F.F. et al. Consumo e digestibilidade aparentes totais e parciais de nutrientes em novilhos alimentados com dietas contendo vários níveis de concentrado. Rev. Bras. Zootec., v.31, p.1543-1552, 2002.

JOHNSON, L.M.; HARRISON, J.H.; DAVIDSON, D. et al. Corn silage management I: Effects of hybrid, maturity, and mechanical processing on chemical and physical characteristics. J. Dairy Sci., v.85, p.833-853, 2002.

KUEHL, R.O. Design of Experiments: Statistical Principles of Research Design and Analysis (2.ed.). Duxbury Press, New York, 2000.

LEÃO, M.I.; COELHO DA SILVA, J.F. Técnicas de fistulação de abomaso em bezerros. CONGRESSO BRASILEIRO DE ZOOTECNIA, REUNIÃO ANUAL DA SOCIEDADE BRASILEIRA DE ZOOTECNIA, 17., 1980, Fortaleza. Anais... Fortaleza: SBZ, 1980.

MELO, W.M.C.; PINHO, R.G.V.; CARVALHO, M.L.M. et al. Avaliação de cultivares de milho para a produção de silagem na região de LavrasMG. Cienc. Agrotec., v.23, p.31-39, 1999.

MORAES, S.A.; PEREIRA, O.G.; GARCIA, R. et al. Consumo e digestibilidade aparente de nutrientes, em bovinos recebendo dietas contendo silagem de milho e concentrado em diferentes proporções. In: Reunião Anual da Sociedade Brasileira de Zootecnia, 39., Recife. Anais... Recife: SBZ, 2002. CD-ROM.
MUCK, R.E.; PITT, R.E. Ensiling and its effect on crop quality silage. In: SILAGE PRODUCTION FROM SEED TO ANIMAL, 67., New York. Proceedings... New York: NRAES, 1993. p.57-66.

NUTRIENT requirements of dairy cattle. 7.ed. Washington, DC: National Academy Press, 2001. p.381.

OFFICIAL methods of analysis, 15.ed. Arlington, VA: AOAC, 1990.

OLIVEIRA, J.S.; SOBRINHO, F.S.; PEREIRA, R.C. et al. Potencial de utilização de híbridos comerciais de milho para silagem na Região Sudeste do Brasil. Rev. Bras. Milho Sorgo, v.2, p.62-71, 2003.

PEREIRA, D.H.; PEREIRA, O.G.; VALADARES FILHO, S.C. et al. Consumo, digestibilidade dos nutrientes e desempenho de bovinos de corte recebendo silagem de sorgo (Sorghum bicolor (L.) Moench) e diferentes proporções de concentrado. Rev. Bras. Zootec., v.35, p.282-291, 2006.

PUTRINO, S.M.; LEME, P.R.; LUZ E SILVA, S. et al. Digestibilidade aparente de dietas com níveis crescentes de concentrado em novilhos Brangus e Nelore. Arq. Bras. Med. Vet. Zootec., v.59, p.406-413, 2007.

QIU, X.; EASTRIDGE, M.L.; WANG, Z. Effects of corn silage hybrid and dietary concentration of forage NDF on digestibility and performance by dairy cows. J. Dairy Sci., v.86, p.3667-3674, 2003.

SATTER, L.D.; AND SLYTER, L.L. Effect of ammonia concentration on rumen microbial protein production in-vitro. Br. J. Nutr., v.32, p.199-208, 1974.

SNIFFEN, C.J.; O'CONNOR, J.D.; VAN SOEST, P.J. et al. A net carbohydrate and protein system for evaluating cattle diets: II. Carbohydrate and protein availability. J. Anim. Sci., v.70, p.3562-3577, 1992.

SILVA, B.C.; PEREIRA, O.G.; PEREIRA, D.H. et al. Consumo e digestibilidade aparente total dos nutrientes e ganho de peso de bovinos de corte alimentados com silagem de Brachiaria brizantha e concentrado em diferentes proporções. Rev. Bras. Zootec., v.34, p.10601069, 2005. 
SOUZA, V.G.; PEREIRA, O.G.; VALADARES FILHO, S.C. et al. Consumo e desempenho de bovinos de corte recebendo silagem de milho e concentrado em diferentes proporções. In: REUNIÃO ANUAL DA SOCIEDADE BRASILEIRA DE ZOOTECNIA, 39., 2002, Recife: Anais... Recife. SBZ, 2002. CD-ROM.

STATISTICAL analysis system. SAS/STAT user's guide. Version 6. 4.ed. Cary: SAS, 1990. $846 \mathrm{p}$.

STERN, M.D.; HOOVER, W.H. Methods for determining and factors affecting rumen microbial protein synthesis: a review. J. Anim. Sci., v.49, p.1590-1603, 1979.

USHIDA, K.; LASSALAS, B.; JOUANY, J.P. Determination of assay parameters for RNA analysis in bacterial and duodenal samples by spectrophotometry: Influence of sample treatment and preservation. Reprod. Nutr., v.25, p.1037-1046, 1985.
VAN SOEST, P.J.; ROBERTSON, J.B.; LEWIS, B.A. Methods for dietary fiber, neutral detergent fiber, and nonstarch polysaccharides in relation to animal nutrition. J. Dairy Sci., v.74, p.35833590, 1991.

VERÁS, A.S.C.; VALADARES FILHO, S.C.; COELHO DA SILVA, J.F. et al. Consumo de digestibilidade aparente em bovinos nelore, não castrados, alimentados com rações com diferentes níveis de concentrado. Rev. Bras. Zootec., v.29, p.2367-2378, 2000.

VIEIRA, P.F. Efeito do formaldeído na proteção de proteínas e lipídios em rações para ruminantes.1980. 98f. Tese de doutorado. Universidade Federal de Viçosa, MG.

XU, S.; HARRISON, J.H.; KEZAR, W. et al. Evaluation of yield, quality, and plant composition of early-maturing corn hybrids harvested at three stages of maturity. J. Anim. Sci., v.11, p.157-165, 1995. 